\title{
MICRONEEDLING WITH PLATELET-RICH PLASMA VERSUS MICRONEEDLING WITH TOPICAL 5\% MINOXIDIL IN PATIENTS WITH ANDROGENETIC ALOPECIA- A COMPARATIVE STUDY
}

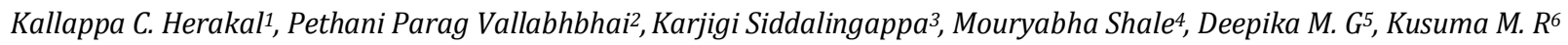 \\ ${ }_{1}^{1}$ Professor \& HOD, Department of Dermatology, Navodaya Medical College \& Research Centre, Raichur. \\ Junior Resident, Department of Dermatology, Navodaya Medical College \& Research Centre, Raichur. \\ 3 Professor, Department of Dermatology, Navodaya Medical College \& Research Centre, Raichur. \\ 4Junior Resident, Department of Dermatology, Navodaya Medical College \& Research Centre, Raichur. \\ 5Junior Resident, Department of Dermatology, Navodaya Medical College \& Research Centre, Raichur. \\ ${ }^{6}$ Senior Resident, Department of Dermatology, Navodaya Medical College \& Research Centre, Raichur.
}

\section{ABSTRACT}

\section{BACKGROUND}

Androgenetic alopecia (AGA) is the most common type of alopecia in men, which is an androgen mediated event. The FDA approved treatment for male AGA are Finasteride and Minoxidil. Platelet-rich plasma (PRP) is a newer method for the treatment of various types of alopecia by providing growth factors in stimulating dermal papilla associated stem cells. Minoxidil helps in new hair growth by causing vasodilatation of scalp blood vessels. Treatment with microneedling showed an accelerated response leading to significant increase in scalp density.

\section{MATERIALS AND METHODS}

Twenty five patients with AGA had undergone microneedling monthly twice followed by Topical $5 \%$ minoxidil solution daily. Minoxidil should be applied 24 hours after microneedling. Another Twenty five patients were subjected to microneedling with Platelet-rich plasma monthly twice. Patients were assessed with the use of the standardised 7-point evaluation scale and patients' subjective hair growth assessment scale before the procedure and even after the procedure. The patients were followed up for 6 months after post-microneedling procedure.

Statistical Analysis- After the data collection, it is entered in MS excel sheet - 2007. Calculated Mean and Standard Deviation for Quantitative data, Frequency and percentage for qualitative data, analysed by using SPSS V 16.0 software. Paired t-test applied for pre-test and post-test of Microneedling with PRP and Microneedling with topical 5\% Minoxidil. Independent sample t-test applied for Microneedling with PRP and Microneedling with topical 5\% Minoxidil. The difference is considered statistically significant whenever $p$ value is 0.05 .

\section{RESULTS}

All patients showed a response of +2 to +3 on a standardised 7-point evaluation scale. The response in the form of new hair growth started after 10-12 sessions. Both treatment modalities were comparably effective in improving hair density and alopecia grade.

\section{CONCLUSION}

Microneedling with PRP is a safe and effective modality in AGA. Even microneedling with minoxidil has good and early response. Thus, both the procedures augment the response even in poor responders to conventional therapy.

\section{KEYWORDS}

Androgenetic Alopecia, Minoxidil, Finasteride, Microneedling, Platelet-rich Plasma.

HOW TO CITE THIS ARTICLE: Herakal KC, Vallabhbhai PP, Siddalingappa K, et al. Microneedling with platelet-rich plasma versus microneedling with topical 5\% minoxidil in patients with androgenetic alopecia- A comparative study. J. Evolution Med. Dent. Sci. 2017;6(26):2182-2186, DOI: 10.14260/Jemds/2017/473

\section{BACKGROUND}

Androgenetic alopecia (AGA) refers to the loss of hair seen with increasing age in genetically predisposed individuals. Since physiological amounts of circulating androgens are needed to express this genetic trait, it is called androgenetic

Financial or Other, Competing Interest: None.

Submission 04-02-2017, Peer Review 19-03-2017,

Acceptance 25-03-2017, Published 30-03-2017.

Corresponding Author:

Dr. Kallappa Herakal,

Professor\& HOD,

Department of Dermatology,

Navodaya Medical College Hospital \& Research Centre,

Raichur.

E-mail: paragpethani@gmail.com

DOI: $10.14260 /$ jemds $/ 2017 / 473$

(c) $($ ) $९$ alopecia. It is so common that in genetically predisposed Individuals, common baldness is considered physiological. ${ }^{1}$ It commonly begins by 20 years of age and affects nearly $50 \%$ of men by the age of 50 years. ${ }^{2}$

Hair follicle has a very complex biologic structure and growth of the hair process is regulated by specific growth cycles. The mature follicle undergoes successive transformation from anagen (active hair shaft production) to catagen (apoptosis-driven regression) to telogen (resting phase with the involution of hair follicle). ${ }^{3}$ Role of apoptosis (by the pathway of caspases cascade) in determining the passage from anagen to catagen is well known. Many growth factors play a fundamental role in the lifelong cyclic transformation of the hair follicle functioning as biologic switches that are turned on and off during the different 
phases, controlling the active phase and promoting apoptosis to induce catagen and telogen. 4

Platelet-rich plasma (PRP) is an autologous preparation of platelets in concentrated plasma. Although the optimal PRP platelet concentration is unclear, the current methods by which PRP is prepared report $300-700 \%$ enrichment, with platelet concentrations consequently increasing to more than 1,000,000 platelets/L. ${ }^{5}$ PRP has attracted attention in several medical fields because of its ability to promote wound healing. Activation of alpha granules of platelets releases numerous proteins, including platelet-derived growth factor (PDGF), transforming growth factor (TGF), vascular endothelial growth factor (VEGF), insulin-like growth factor (IGF), epidermal growth factor (EGF) and interleukin (IL)1.6,7 It is hypothesised that growth factors released from platelets may act on stem cells in the bulge area of the follicles, stimulating the development of new follicles and promoting neovascularisation. ${ }^{8}$

A Dermaroller is a skin needling device with many small surgical needles. Dermaroller with needle lengths between $0.5 \mathrm{~mm}$ to $1.5 \mathrm{~mm}$ are suited for Androgenetic Alopecia. The needle diameter (thickness) is $0.25 \mathrm{~mm}$ at their base.

Studies on repeated Microneedling stimulation by Jeong et $\mathrm{al}^{9}$ and Kim et al showed the enhanced expression of hair related genes and stimulation of hair in mice. Kim et al also noted earlier and faster hair re-growth with more shiny texture of the hair in microneedle treated group than the untreated mice group. The authors also suggested that microneedle roller could be useful to treat hair loss refractory to Minoxidil therapy.

Minoxidil and Finasteride are the only FDA approved treatment modalities for AGA. The realisation of its affectivity came through a serendipitous observation by Zappacosta in 1980 while treating a patient with hypertension. ${ }^{10}$ Minoxidil, an orally effective vasodilator, was then used topically for alopecia areata (AA) and AGA. It may perhaps act as a potassium channel opener thereby enhancing the growth of suboptimal follicles in vivo and in vitro. ${ }^{11}$ It is used in concentration of $2 \%$ in females and $5 \%$ in males applied 1 $\mathrm{mL}$ twice daily.

\section{MATERIALS AND METHODS}

\section{Methods of Allocation}

It included twenty-five patients in each group, Men between 25 years and 35 years of age with mild to moderate (III or IV) AGA, according to Norwood-Hamilton grading scale were enrolled in the study.

Twenty-five patients with AGA had undergone microneedling monthly twice followed by Topical $5 \%$ minoxidil solution daily which should be applied 24 hours after microneedling. Another Twenty-five patients were subjected to microneedling with Platelet-rich plasma monthly twice.

Both groups, microneedling was done with Dermaroller of $1.5 \mathrm{~mm}$ sized needles, rolled over the affected areas of the scalp in a longitudinal, vertical, and diagonal directions until mild erythema. Duration of study is 6 months with 18 months of followup. PRP was prepared by drawing $10 \mathrm{~mL}$ of patient's own blood and centrifuging it for $5 \mathrm{~min} .-1500 \mathrm{rpm}$,
15 min.-2500 rpm by double spin method and platelet-rich plasma collected. The procedure was carried out with informed consent, under aseptic condition after application of topical anaesthetic.

\section{Statistical Method \\ Hair Counts}

The target thinning area of $1 \mathrm{~cm}$ diameter, on the vertex was defined by two diagonally placed tattoos to ensure reproducibility. Then, the hair counts were obtained from colour photographs of remnants of the shaven hair in the target area. Colour Photographs of target area were taken before treatment, after 6 and 18 months of treatment and patients were assessed with 7-point evaluation scale Paired baseline and post-treatment photographs were independently reviewed by a blinded evaluator.

Baseline follicular units were manually counted with help of TrichoScan in this area by dividing into small quadrants.

Patients were assessed with the use of the standardised 7-point evaluation scale and patient's subjective hair growth assessment scale.

$-3=$ greatly decreased,

-2 = moderately decreased,

-1 = slightly decreased,

$0=$ no change,

$+1=$ slightly increased,

$+2=$ moderately increased,

$+3=$ greatly increased.

The procedure was repeated every 15 days for duration of six months. The patients were followed up for 18 months after post microneedling procedure to assess the sustainability.

\section{Statistical Analysis}

After the data collection, it is entered in MS excel sheet 2007. Calculated Mean and Standard Deviation for Quantitative data, Frequency and percentage for qualitative data, analysed by using SPSS V 16.0 software. Paired t-test applied for pre-test and post-test of Microneedling with PRP and Microneedling with topical 5\% Minoxidil. Independent sample t-test applied for Microneedling with PRP and Microneedling with topical 5\% Minoxidil. The difference is considered statistically significant whenever $p$ value is $<0.05$ and $p$ value is $<0.01$ is highly significant.

\section{RESULTS}

Before treatment all our patients $(100 \%)$ had a positive hair pull test with mean number of 15 hairs. After 6 months of therapy, hair pull test was negative in $21(82 \%)$ patients in Microneedling with PRP group and 20 (80\%) patients in microneedling with topical 5\% minoxidil group. Hair count depicted average no. of 62 hair follicular units over marked area before starting the treatment and after 18 months, average no. of follicular units was 94 in Microneedling with PRP group and 92 in microneedling with topical 5\% minoxidil group. 
Hair Growth Assessment Scale

\begin{tabular}{|c|c|c|}
\hline & $\begin{array}{c}\text { No. of Patients showing Greatly } \\
\text { Increased in Hair Growth } \\
\text { (+3 response) }\end{array}$ & $\begin{array}{c}\text { No. of Patients showing Moderately } \\
\text { Increased in Hair Growth } \\
\text { (+2 response) }\end{array}$ \\
\hline Microneedling with PRP & $11(44 \%)$ & $14(56 \%)$ \\
\hline Microneedling with 5\% Minoxidil & $9(36 \%)$ & $16(64 \%)$ \\
\hline \multicolumn{2}{|c|}{ Table 1 } \\
\hline
\end{tabular}

Paired Samples Statistics For Microneedling with PRP

\begin{tabular}{|l|c|c|c|c|c|}
\hline & & Mean & N & Std. Deviation & Std. Error Mean \\
\hline \multirow{2}{*}{ Pair 1 } & Microneedling with PRP Pre-treatment & 62.0400 & 25 & 3.97366 & .79473 \\
\cline { 2 - 6 } & Microneedling with PRP 18 months after treatment & 94.0000 & 25 & 3.51188 & .70238 \\
\hline \multicolumn{4}{|c|}{ Table 2 } \\
\hline
\end{tabular}

Paired Samples Test for Microneedling with PRP

\begin{tabular}{|c|c|c|c|c|c|c|c|c|c|}
\hline & & \multicolumn{5}{|c|}{ Paired Differences } & \multirow{3}{*}{$\mathbf{t}$} & \multirow{3}{*}{ df } & \multirow{3}{*}{$\begin{array}{c}\text { Sig. } \\
\text { (2-tailed) }\end{array}$} \\
\hline & & \multirow[t]{2}{*}{ Mean } & \multirow{2}{*}{$\begin{array}{l}\text { Std. } \\
\text { Deviation }\end{array}$} & \multirow{2}{*}{$\begin{array}{l}\text { Std. Error } \\
\text { Mean }\end{array}$} & \multicolumn{2}{|c|}{$\begin{array}{l}95 \% \text { Confidence Interval of } \\
\text { the Difference }\end{array}$} & & & \\
\hline & & & & & Lower & Upper & & & \\
\hline Pair 1 & $\begin{array}{l}\text { Microneedling with } \\
\text { PRP Pre-treatment- } \\
\text { Microneedling with } \\
\text { PRP } 18 \text { months after } \\
\text { treatment }\end{array}$ & & & & 30.28973 & 33.63027 & & & \\
\hline \multicolumn{10}{|c|}{ Table 3} \\
\hline
\end{tabular}

Paired Samples Statistics Microneedling with 5\% Minoxidil

\begin{tabular}{|c|c|c|c|c|c|}
\hline & & Mean & $\mathbf{N}$ & Std. Deviation & Std. Error Mean \\
\hline \multirow{2}{*}{ Pair 2 } & Microneedling with 5\% Minoxidil pre treatment & 62.0400 & 25 & 3.97366 & .79473 \\
\cline { 2 - 6 } & Microneedling with 5\% Minoxidil after 18 months of treatment & 92.0000 & 25 & 3.96863 & .79373 \\
\hline \multicolumn{6}{|c|}{ Table 4 } \\
\hline
\end{tabular}

Paired Samples Test Microneedling with 5\% Minoxidil

\begin{tabular}{|c|c|c|c|c|c|c|c|c|c|}
\hline & & \multicolumn{5}{|c|}{ Paired Differences } & \multirow{3}{*}{$\mathbf{t}$} & \multirow{3}{*}{ df } & \multirow{3}{*}{$\begin{array}{c}\text { Sig. } \\
\text { (2-tailed) }\end{array}$} \\
\hline & & \multirow[t]{2}{*}{ Mean } & \multirow{2}{*}{$\begin{array}{c}\text { Std. } \\
\text { Deviation }\end{array}$} & \multirow{2}{*}{$\begin{array}{c}\text { Std. Error } \\
\text { Mean }\end{array}$} & \multicolumn{2}{|c|}{$\begin{array}{c}95 \% \text { Confidence Interval of } \\
\text { the Difference }\end{array}$} & & & \\
\hline & & & & & Lower & Upper & & & \\
\hline Pair 1 & $\begin{array}{l}\text { Microneedling with } \\
5 \% \text { Minoxidil } \\
\text { pretreatment - } \\
\text { Microneedling with } \\
\text { 5\% Minoxidil after } 18 \\
\text { months of treatment }\end{array}$ & 29.9600 & 5.98944 & 1.19789 & 27.48768 & 32.43232 & 25.011 & 24 & $\begin{array}{l}.000<0.01 \\
\text { Highly Sig }\end{array}$ \\
\hline & & & & Tabl & & & & & \\
\hline
\end{tabular}

\section{Group Statistics}

\begin{tabular}{|c|c|c|c|c|c|}
\hline & Group & N & Mean & Std. Deviation & Std. Error Mean \\
\hline \multirow{2}{*}{ Post } & Microneedling with PRP & 25 & 94.0000 & 3.51188 & .70238 \\
\cline { 2 - 6 } & Microneedling with 5\% Minoxidil & 25 & 92.0000 & 3.96863 & .79373 \\
\hline \multicolumn{5}{|c|}{ Table 6 } \\
\hline
\end{tabular}

\begin{tabular}{|c|c|c|c|c|c|c|c|c|}
\hline & & \multicolumn{7}{|c|}{ t-test for Equality of Means } \\
\hline & & \multirow[t]{2}{*}{$\mathbf{t}$} & \multirow[t]{2}{*}{ df } & \multirow{2}{*}{$\begin{array}{c}\text { Sig. } \\
\text { (2-tailed) }\end{array}$} & \multirow{2}{*}{$\begin{array}{c}\text { Mean } \\
\text { Difference }\end{array}$} & \multirow{2}{*}{$\begin{array}{l}\text { Std. Error } \\
\text { Difference }\end{array}$} & \multicolumn{2}{|c|}{\begin{tabular}{|c|}
$\begin{array}{c}95 \% \\
\text { of Confidence Interval } \\
\text { of Difference }\end{array}$ \\
\end{tabular}} \\
\hline & & & & & & & Lower & Upper \\
\hline $\mathrm{t}$ & $\begin{array}{c}\text { Microneedling with PRP- } \\
\text { Microneedling with 5\% Minoxidil }\end{array}$ & 1.887 & 48 & $\begin{array}{l}.065>0.05 \\
\text { Not Sig }\end{array}$ & 2.00000 & 1.05987 & -.13102 & 4.13102 \\
\hline \multicolumn{9}{|c|}{ Table 7} \\
\hline
\end{tabular}


All patients in each group showed a response of +2 to +3 on standardised 7-point evaluation scale. Out of Twenty five patients with microneedling followed by Topical $5 \%$ minoxidil solution, 16 (64\%) patients showed moderately increased and 9 (36\%) patients showed greatly increased hair growth in 7-point evaluation scale. And another Twenty five patients with microneedling followed by PRP, 14 (56\%) patients showed moderately increased and 11 (44\%) patients showed greatly increased hair growth in 7-point evaluation scale. While the response in the form of new hair growth started after 8-10 sessions in PRP group. Both treatment modalities were comparably effective in improving hair density and alopecia grade. Among patients using minoxidil, 5 developed irritation, 2 headache and 2 contact dermatitis. Among patients on microneedling and PRP, 3 developed discomfort over scalp, 2 developed erythema.

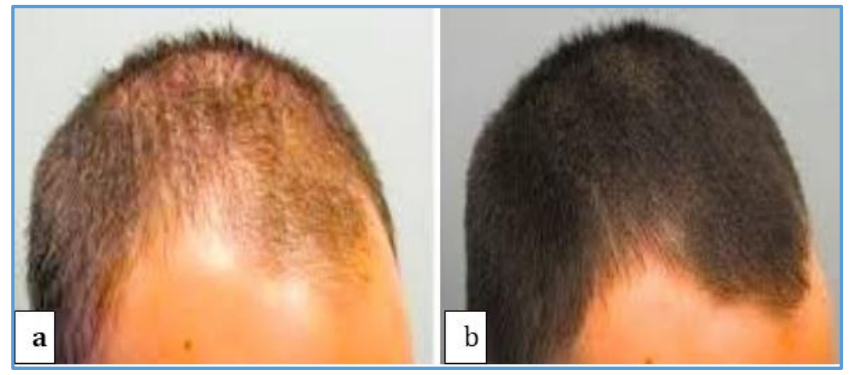

a) Before \& b) 6 Months after Treatment with Microneedling with PRP

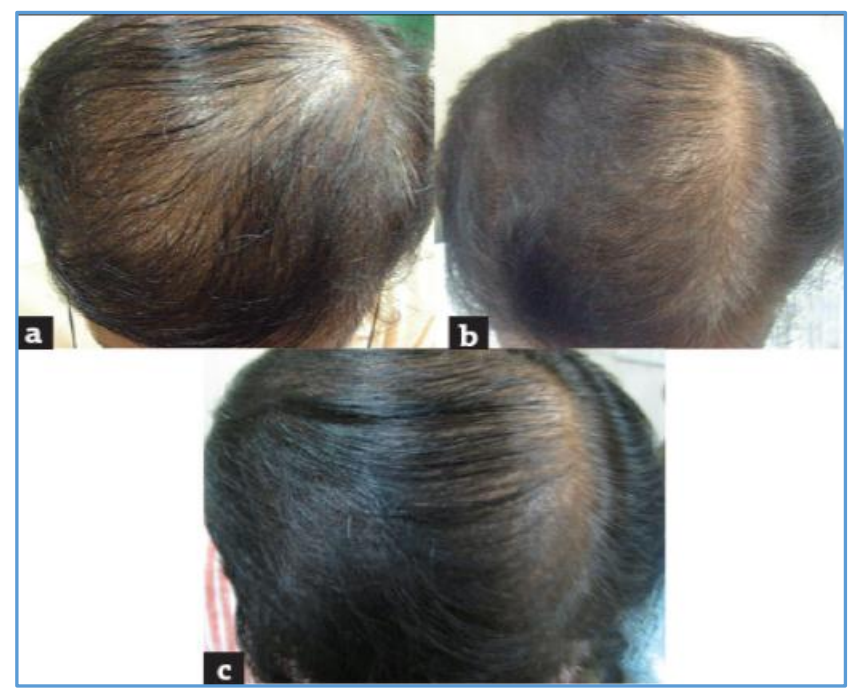

a) Before b) One month after \& c) 6 months after Microneedling with 5\% Minoxidil

\section{DISCUSSION}

Hair loss has a significant influence on psychological distress and is associated with low self-esteem and depression. Treatment options for androgenic alopecia are very limited and include topical minoxidil and oral finasteride (FDA approved) either alone or in combination. ${ }^{12}$, Local side effects of Minoxidil include aggravation of local inflammatory scalp dermatoses (seborrhoeic dermatitis, psoriasis), allergic contact dermatitis, irritation and pain. Systemic side effects of Minoxidil are Hypotension, Headache and hypertrichosis. Growth factors are known to activate the proliferative phase and transdifferentiation of hair and stem cells and produce new follicular units; bFGF is reported to promote the in vitro proliferation of papilla cells, and thereby plays a key role in elongating hair shaft. ${ }^{13}$

Mechanisms of hair re-growth induced by Microneedling include Release of platelet derived growth factor, epidermal growth factors are increased through platelet activation and skin wound regeneration mechanism; activation of stem cells in the hair bulge area under wound healing conditions which is caused by a Dermaroller; overexpression of hair growth related genes vascular endothelial growth factor, B catenin, Wnt3a, and Wnt10b .9,14

In our study, Microneedling is a safe and promising tool in hair stimulation. PRP with microneedling and Minoxidil with microneedling is simple, cost effective has good safety profile and promising treatment option for AGA. Sample size is very small. Mean followup of patient is also short to draw conclusion regarding the long-term effectiveness of treatment.

A study done by Durat $\mathrm{R}$ et al on 50 patients with microneedling with Minoxidil and 50 patients only with Minoxidil showed that in Microneedling group 41 (82\%) versus $2(4 \%)$ in the Minoxidil group reported more than $50 \%$ improvement after 12 weeks. This study showed that Microneedling with Minoxidil treated group was statistically superior to Minoxidil treated group in promoting hair growth in men with AGA. 15

\section{CONCLUSION}

Microneedling with PRP is a safe and effective modality in AGA. Even microneedling with minoxidil has good and early response. Thus, both the procedures augment the response even in poor responders to conventional therapy. PRP with microneedling is simple, cost-effective, has good safety profile and is a promising treatment option for patients with androgenetic alopecia. Further studies are needed with longer followup with larger sample size.

\section{REFERENCES}

[1] Wadhwa SL, Khopkar U, Nischal KC. Hair and Scalp disorders. In: Valia RG, Valia AR. eds. IADVL textbook of dermatology. $3^{\text {rd }}$ edn. Bhalani Publishing House 2008:864-949.

[2] Ellis JA, Sinclair R, Harrap SB. Androgenetic alopecia: pathogenesis and potential for therapy. Expert Rev Mol Med 2002;4(22):1-11.

[3] Kaufman KD, Olsen EA, Whiting D, et al. Finasteride in the treatment of men with androgenetic alopecia. Finasteride male pattern hair loss study group. J Am Acad Dermatol 1998;39(4 Pt 1):578-89.

[4] Price VH. Treatment of hair loss. N Engl J Med 1999;341(13):964-73.

[5] Li ZJ, Choi HI, Choi DK, et al. Autologous platelet rich plasma: a potential therapeutic tool for promoting hair growth. Dermatol Surg 2012;38(7 Pt 1):1040-6.

[6] Marx RE. Platelet-rich plasma: evidence to support its use. J Oral Maxillofac Surg 2004;62(4):489-96.

[7] Eppley BL, Pietrzak WS, Blanton M. Platelet-rich plasma: a review of biology and applications in plastic surgery. Plast Reconstr Surg 2006;118(6):147e-59e. 
[8] Uebel CO, da Silva JB, Cantarelli D, et al. The role of platelet plasma growth factors in male pattern baldness surgery. Plast Reconstr Surg 2006;118(6):1458-67.

[9] Jeong K, Lee YJ, Kim JE, et al. Repeated microneedle stimulation induce the enhanced expression of hairgrowth-related genes. Int J Trichology 2012;4(2):11730.

[10] Zappacosta AR. Reversal of baldness in a patient receiving minoxidil for hypertension. $\mathrm{N}$ Engl J Med 1980;303(25):1480-1.

[11] Buhl AE. Minoxidil's action in hair follicles. J Invest Dermatol 1991;96(5):73S-4S.

[12] Olsen EA, Weiner MS, Delong ER, et al. Topical minoxidil in early male pattern baldness. J Am Acad Dermatol 1985;13(2 Pt 1):185-92.
[13] Katsuoka K, Schell H, Wessel B, et al. Effects of epidermal growth factor, fibroblast growth factor, minoxidil and hydrocortisone on growth kinetics in human hair bulb papilla cells and root sheath fibroblasts cultured in vitro. Arch Dermatol Res 1987;279(4):247-50.

[14] O'Toole EA, Mellerio JE. Wound healing. In: Burns TB, Cox N, Griffiths C, eds. Rook's textbook of dermatology. $8^{\text {th }}$ edn. Blackwell Publishing 2010:14.114.27.

[15] Dhurat R, Sukesh M, Avhad G, et al. A randomized evaluator blinded study of effect of microneedling in androgenetic alopecia: a pilot study. Int J Trichology 2013;5(1):6-11. 